\title{
Production Potential of Allelopathic Rice, Cymbopogon, Desmodium, Mucuna and Maize
}

\author{
M. G. Kaiira ${ }^{1}$, G. N. Chemining'wa ${ }^{2}$, F. Ayuke ${ }^{3}$, Y. Baguma ${ }^{4}$ \& E. Atwijukire ${ }^{4}$ \\ ${ }^{1}$ Buginyanya Zonal Agricultural Research and Development Institute, Mbale, Uganda \\ ${ }^{2}$ Department of Plant Science and Crop Protection, University of Nairobi, Nairobi, Kenya \\ ${ }^{3}$ Department of Land Resource Management and Agricultural Technology, University of Nairobi, Nairobi, \\ Kenya \\ ${ }^{4}$ National Crops Resources Research Institute (NaCRRI), Namulonge, Uganda \\ Correspondence: M. G. Kaiira, Buginyanya Zonal Agricultural Research and Development Institute, Mbale, \\ Uganda. E-mail: moseskaiira@gmail.com
}

Received: November 20, 2019

Accepted: July 20, 2021

Online Published: August 15, 2021

doi:10.5539/jas.v13n9p202

URL: https://doi.org/10.5539/jas.v13n9p202

\begin{abstract}
Allelochemicals regulate the productivity of crop ecosystems. A screen house experiment was conducted (2016) at the National Crops Resources Research Institute, Namulonge, Uganda to determine the effects of NERICA 1 rice (an interspecific hybrid between Oryza sativa and O. glaberrima species), Cymbopogon nardus (C), Desmodium uncinatum (D), Mucuna pruriens (Mc) and LONGE 6H, Zea mays (Mz) on crop relative growth rates (RGR), nitrogen (N), phosphorus (P) and potassium (K) nutrient levels. One field study was conducted on a farm (2017) to establish the allelopathic interactive effects of RCDMcMz on Striga hermonthica (a parasitic weed), crop competition and productivity. Data was collected on striga, RMz growth, nutrient levels and yield. Potted rice reduced (30\%-47\%) in root length but Mz leaf length increased (31\% \& 15\%) with Mc \& D. RMc reduced (73\%) striga and increased rice RGR (14-42 days). RD similarly reduced (67\%) striga. RC increased (96\%, 44\% \& 73\%) rice NPK uptake, RGR (14-42 days), reduced (57\%) striga and increased (1.56) the combined land equivalent ratio (CLER) and rice grain yields. RMz reduced (16\%, 38\% \& 38\%) rice NPK reserves, RGR (14-42 days), CLER (1.0), grain yields and increased (36\%) striga. RD recorded higher CLER (1.56). MzMc reduced (15\% \& 27\%) maize P uptake and NP uptake increased (42\% \& 9.3\%) under MzC \& MzD (73\% \& 29\%). RMc increased rice RGR (14-42 days). Maize RGR (14-28 days) increased under MzD, MzMc \& MzC and reduced (28-42 days) under MzD, RC \& MzMc.. The ecosystems' productivity was attributed to allelopathy.
\end{abstract}

Keywords: allelochemicals, intercropping, land equivalent ratio, NPK uptake, relative growth rates, striga

\section{Introduction}

Secondary metabolites in plants have been investigated by phytochemists and classified as waste products (Zhao-Hui, 2010). The metabolites have been considered as potential allelochemicals which play significant roles in shaping crop interactions and communities, and subsequently their productivity. Allelochemicals influence crop physiological processes, such as increased cell membrane permeability, cell proliferation, and DNA synthesis in plant meristems, thereby affecting crop growth rates (Harun et al., 2014). In addition, allelochemicals can restrain nutrient absorption and growth regulatory system activities, which subsequently affect normal growth of plants and may cause death of plant tissue (F. Cheng \& Z. Cheng, 2015). It is reported that rice and maize cropping systems are affected by allelochemicals and the parasitic weed Striga hermonthica. But, some rice cultivars have been reported to tolerate striga (Rodenburg et al., 2015).

Burgos et al. (2004) observed significant inhibition of N, P and K uptake and regeneration of root cap cells, and thus, inhibited crop growth due to allelochemicals. Nishida et al. (2005) reported that monoterpenoids affected cell proliferation and DNA synthesis in plant meristems. Geng et al. (2009) noted that a low concentration of dibutyl phthalate increased the absorption of N, but decreased P and K nutrient absorption. Chaimovitsh et al. (2012) reported Citral metabolite of Cymbopogon citrates to cause disruption of microtubules in wheat and Arabidopsis thaliana L. roots. Constantine et al. (2013) reported that Striga asiatica and Rhamphicarpa fistulosa adversely affect rice physiology and grain yields. Mbogo et al. (2013) reported a negative correlation between emerged 
striga/striga damage ratings and yield. Kanampiu et al. (2018) noted that intercropping herbicide-resistant maize varieties with legumes was a more effective method for $S$. hermonthica control than monoculture. Kaiira et al. (2019, 2021a, 2021b), reported NERICA 1 rice, C. nardus, D. uncinatum, M. pruriens and Zea mays (LONGE 6H), the five study crop species as highly allelopathic.

Intercropping is a system of growing two or more crops, simultaneously, on the same land with special spatial arrangement. Cropping system productivity is highly enhanced through intercropping as higher returns per investment are realized per unit area than under sole crops (Willey, 1979). Paired row planting using additive series was adopted in this investigation for higher total output from the intercropping systems as the population of the base rice crop was maintained with bonus intercrop yield. Gozubenli et al. (2004) reported benefits from twin row cropping of maize. Rana et al. (2013) reported higher monetary returns with substantially higher yield advantages from intercropping systems over sole rice crops. The higher monetary benefits clearly indicated yield advantages of intercropping over monocropping of rice. Several cultivars grown under intercropping ecosystems are however reported to be allelopathic. Therefore, the objectives of the study were: (1) to determine the growth, nutrient uptake and soil nutrient reserve at harvest for allelopathic rice, cymbopogon, desmodium, mucuna and maize; (2) to evaluate different allelopathic rice-based intercropping systems for Striga hermonthica weed control and rice productivity.

\section{Materials and Methods}

A screen house pot study was conducted at the National Crops Resources Research Institute, Namulonge, Uganda during 2016, and a field experiment was conducted at Ikulwe Research Station and at a farm at Pallisa, Uganda during 2017.

\subsection{Screen House}

\subsubsection{Treatments and Experimental Design}

Two different species each of Oryza sativa, Cymbopogon nardus, Desmodium uncinatum, Mucuna pruriens, and Zea mays were planted in pots with $6 \mathrm{~kg}$ of air-dried, loam-clay forest soil. The crops were also planted as sole crops in a randomized complete block design with five replications. Two replicates were used for data collection for destructive samples. The 15 treatments included 10 crop combinations of two different species per pot namely rice/maize, maize/desmodium, cymbopogon/desmodium, rice/desmodium, cymbopogon/mucuna, maize/cymbopogon, rice/mucuna, desmodium/mucuna, maize/mucuna, rice/cymbopogon and 5 sole crops. Crops were planted and thinned at seven days after emergence of rice (DAE) to four plants for rice and desmodium, mucuna (one plant) and maize (two plants). C. nardus were trimmed as two homogenous suckers to $10 \mathrm{~cm}$ height before being established in similar pots. The crops were not supplied with any fertilizer but watered with $150 \mathrm{ml}$ of tap water every two days. Hand weed removal was completed at $21 \mathrm{DAE}$ during the eight week long pot study. No pests or diseases were observed.

\subsubsection{Data Recording}

Plant height, leaf length, leaf width were measured, and the leaves with more than $75 \%$ green area were counted every 2 weeks up to 56 DAE on one tagged plant per pot. During the same period, root length was measured on harvested samples and dry matter determined every 14 days on an electronic balance after oven drying of the samples at $80^{\circ} \mathrm{C}$ for 24 hours to constant weight. The Relative Growth Rate (RGR) for the crops was calculated using the formula: $\mathrm{RGR}=\left(\ln \mathrm{W}_{2}-\ln \mathrm{W}_{1}\right) /\left(\mathrm{T}_{2}-\mathrm{T}_{1}\right)$, where; $\ln \mathrm{W}_{1}$ and $\ln \mathrm{W}_{2}$ are the means of the natural logarithm for transformed plant weight $\mathrm{W}_{1}$ and $\mathrm{W}_{2}$ at time $\mathrm{T}_{1}$ and $\mathrm{T}_{2}$ respectively. Air-dried soil samples prior to planting, soil and whole plants at harvest were subjected to chemical analysis for N, P \& K nutrient uptake and reserves in the soil at harvest using standard methods described by Okalebo et al. (2002).

\subsection{Field Study}

\subsubsection{Study Site}

A field study was conducted at Ikulwe research station and on farm at Pallisa during 2017. Ikulwe is located at $00^{\circ} 26^{\prime} 23.2^{\prime \prime} \mathrm{N} 033^{\circ} 28^{\prime} 40.9^{\prime \prime} \mathrm{E}$, at 1209 meters above sea level. The area received a total of $543 \mathrm{~mm}$ of the $1230 \mathrm{~mm}$ annual rainfall during the cropping season with minimum and maximum temperatures of 18 and $30^{\circ} \mathrm{C}$ respectively. Pallisa is located at $1^{\circ} 13^{\prime} 33.2^{\prime \prime} \mathrm{N}$ and $33^{\circ} 46^{\prime} 47.2^{\prime \prime} \mathrm{E}$. The total precipitation received was $450 \mathrm{~mm}$ against the annual rainfall of $990 \mathrm{~mm}$ and the temperatures recorded as minimum and maximum were $19{ }^{\circ} \mathrm{C}$ and $31{ }^{\circ} \mathrm{C}$, respectively. Both experimental sites had sandy loam soils. 


\section{(1) Treatments and Experimental Design}

Maize, mucuna, desmodium and cymbopogon were tested as sole and intercrops in rice under a randomized complete block design with three replicates. The experimental units measured $5 \mathrm{~m} \times 8 \mathrm{~m}$ with $2 \mathrm{~m}$ between the plots. The crops were planted as sole upland rice in paired rows at $40 / 20 \mathrm{~cm} \times 12.5 \mathrm{~cm}$ (one plant/hill) and as rice intercropped with one row of each crop (maize, mucuna or desmodium) thinned to one plant/hill. The spacing of desmodium, mucuna and maize intercrops within rows were $10 \mathrm{~cm}, 120 \mathrm{~cm}$ and $30 \mathrm{~cm}$ respectively. Four uniformly cut $10 \mathrm{~cm}$ long cymbopogon suckers were planted per hill as intercrops at a distance of $45 \mathrm{~cm}$ within the row. Sole crops of cymbopogon $(60 \mathrm{~cm} \times 45 \mathrm{~cm})$, desmodium $(45 \mathrm{~cm} \mathrm{x} 10 \mathrm{~cm})$, mucuna $(60 \mathrm{~cm} \times 120$ $\mathrm{cm})$, rice in paired rows $(40 / 20 \mathrm{~cm} \times 12.5 \mathrm{~cm})$ and maize $(75 \mathrm{~cm} \times 30 \mathrm{~cm})$ were sown as in intercropping systems on the same date. Nitrogen, phosphorus and potassium $\left(60: 30: 30 \mathrm{~kg} \mathrm{ha}^{-1}\right)$ fertilisers were applied to rice and none to the associated intercrops. All P \& K fertilisers were applied by band placement at planting and $\mathrm{N}$ was applied in two equal splits at planting $\left(30 \mathrm{~kg} \mathrm{ha}^{-1}\right)$ and panicle initiation $\left(30 \mathrm{~kg} \mathrm{ha}^{-1}\right)$ stages. The sources of N, P \& $\mathrm{K}$ were urea $(46 \% \mathrm{~N})$, single super phosphate $\left(16 \% \mathrm{P}_{2} \mathrm{O}_{5}\right)$ and muriate of potash $\left(60 \% \mathrm{~K}_{2} \mathrm{O}\right)$, respectively. Hand hoeing was done uniformly at $21 \mathrm{DAE}$ and $42 \mathrm{DAE}$ in all the plots. There were no pests and disease incidences, thus, no control measures were administered in all treatments.

\section{(2) Data Recording}

Five plants from individual net plots of each crop were randomly selected and tagged at 14 DAE for biometric observations. The plant heights were measured from the ground to the base of the last fully opened leaf in rice, maize and cymbopogon, and from the ground to the tip of the youngest leaf for desmodium and mucuna. The length and width of the plant leaves were taken by measuring the longest leaf and widest leaf parts, respectively. The green leaves were counted weekly on tagged plants in all the treatments up to flowering stages. Data were collected on the number of tillers, number of striga per 100 rice plants and the leaf number. Data collection ended at the panicle initiation stage of rice and tasselling maize. The 2 boarder rows per plot together with two plants at both ends of rows in all sole crops were harvested as guard rows. Under intercropping treatments, one row of the base crop and another of the intercrop on each side of the plot were harvested as guard rows and net plot crops were harvested for data collection. The number of panicles per plant, filled panicles per plant, total grains per plant and filled grains per panicle were determined on 10 earmarked plants. The yield per hectare was determined using harvested grain rice in 30 net plots each measuring $30 \mathrm{~m}^{2}$ at 90 DAE. Desmodium, cymbopogon and mucuna vegetative materials were harvested from the net plots at 120 DAE. The fresh biomass per net plot and economic yield for mucuna were also determined.

\section{(3) Competitive Indices}

The yield advantage was assessed quantitatively by land equivalent ratio (LER) and competitive ratios (CR). The LER was calculated (Mead \& Willey, 1980) for each of the components (Partial LER) and their combination (Combined LER) as follows: $\mathrm{LER}=\left(\mathrm{Y}_{\mathrm{ij}} / \mathrm{Y}_{\mathrm{ii}}\right)+\left(\mathrm{Y}_{\mathrm{ji}} / \mathrm{Y}_{\mathrm{jj}}\right)$, where, $\mathrm{LER}=$ Combined land equivalent ratio, $\mathrm{Y}=$ Yield per hectare; ii and $\mathrm{jj}=$ Pure stands of species $\mathrm{i}$ and $\mathrm{j} ; \mathrm{ij}$ and $\mathrm{ji}=$ Intercrops. The CR index was calculated (Willey \& Rao, 1980) using the following formula: $C R A=($ LERA/LERB) $(Z I B / Z I A)$, where, ZIA = sown proportion of crop A (in crop A intercropping with B); ZIC = sown proportion of crop B (in crop B intercropping with A).

\subsection{Data Analysis}

Collected data were subjected to analysis of variance (ANOVA) using Genstat statistical package $\left(13^{\text {th }}\right.$ edition, 2013). The significant differences between treatments means were separated using Fisher's least significant difference (LSD) test at $\mathrm{P} \leq 0.05$.

\section{Results}

\subsection{Growth of Rice and Maize in Pots under a Screen House}

Rice plant height was not influenced by potted plants (Table 1). Potting rice with mucuna, maize, desmodium and cymbopogon significantly $(\mathrm{P} \leq 0.05)$, reduced the rice root length $(4.8-6.3 \mathrm{~cm})$ relative to sole rice $(9.0 \mathrm{~cm})$. Shoot dry matter, leaf number, leaf length and leaf width for rice plants were not significantly affected by potting. Potting maize with mucuna or desmodium increased the maize leaf length to $84.30 \mathrm{~cm}$ and $75.70 \mathrm{~cm}$ respectively, relative to sole maize $(64.3 \mathrm{~cm})$. Maize plant height, root length, dry matter, leaf number and width of leaves were not influenced by potting.

\subsection{Growth of Intercropped Rice under Field Conditions}

Intercropping rice with cymbopogon or desmodium significantly $(\mathrm{P} \leq 0.05)$, increased rice tillers per plant at 21 DAE on-station (4.2 tillers \& 3.7 tillers) and on-farm (3.4 tillers \& 2.8 tillers) relative to sole rice (3.2 tillers \& 2.7 
tillers) at both sites. The rice tillers under cymbopogon and desmodium intercrops, similarly, increased at 36 DAE on-station (6.8 tillers \& 6.0 tillers) and on-farm (5.8 tillers \& 4.8 tillers). At panicle initiation stage (55 DAE) the tillers reduced relative to counts at $36 \mathrm{DAE}$ under all treatments.

Table 1. Growth of rice potted with mucuna, maize, desmodium or cymbopogon and striga incidences under screen house and field conditions

\begin{tabular}{|c|c|c|c|c|c|c|c|c|c|}
\hline \multirow{4}{*}{ Potted plants } & \multicolumn{5}{|c|}{ Screen House } & \multicolumn{4}{|c|}{ Field } \\
\hline & \multicolumn{5}{|c|}{ On Station } & \multicolumn{4}{|c|}{ On Farm } \\
\hline & \multicolumn{2}{|c|}{ Growth parameters } & \multicolumn{3}{|c|}{ Tillers } & \multicolumn{4}{|c|}{ Tillers and Striga Weed } \\
\hline & Height $(\mathrm{cm})$ & $\mathrm{RL}(\mathrm{cm})$ & $21 \mathrm{DAE}$ & $36 \mathrm{DAE}$ & $55 \mathrm{DAE}$ & $21 \mathrm{DAE}$ & $36 \mathrm{DAE}$ & $55 \mathrm{DAE}$ & Striga/HP \\
\hline Rice sole & $17.67 \mathrm{ab}$ & $9.00 \mathrm{a}$ & $3.17 \mathrm{c}$ & $5.33 \mathrm{c}$ & $3.83 \mathrm{c}$ & $2.67 \mathrm{c}$ & $4.62 \mathrm{c}$ & $2.83 \mathrm{~b}$ & $81.30 \mathrm{~b}$ \\
\hline Rice + Mucuna & $22.00 \mathrm{a}$ & $5.00 \mathrm{~b}$ & $2.83 \mathrm{~d}$ & $4.33 \mathrm{~d}$ & $2.79 \mathrm{~d}$ & $2.27 \mathrm{~d}$ & $3.83 \mathrm{~d}$ & $2.28 \mathrm{c}$ & $21.70 \mathrm{c}$ \\
\hline Rice + Maize & $22.00 \mathrm{a}$ & $6.33 \mathrm{~b}$ & $2.67 \mathrm{~d}$ & $3.17 \mathrm{e}$ & $2.70 \mathrm{~d}$ & $1.03 \mathrm{e}$ & $3.27 \mathrm{e}$ & $1.00 \mathrm{~d}$ & $110.30 \mathrm{a}$ \\
\hline Rice + Desmodium & $17.00 \mathrm{ab}$ & $4.83 \mathrm{~b}$ & $3.67 \mathrm{~b}$ & $6.00 \mathrm{~b}$ & $4.17 \mathrm{~b}$ & $2.83 \mathrm{~b}$ & $4.83 \mathrm{~b}$ & $3.47 \mathrm{a}$ & $26.70 \mathrm{c}$ \\
\hline Rice + Cymbopogon & $12.33 \mathrm{~b}$ & $5.00 \mathrm{~b}$ & $4.17 \mathrm{a}$ & $6.83 \mathrm{a}$ & $5.50 \mathrm{a}$ & $3.39 \mathrm{a}$ & $5.83 \mathrm{a}$ & $3.40 \mathrm{a}$ & $35.30 \mathrm{c}$ \\
\hline P-value & 0.032 & 0.005 & $<0.001$ & $<0.001$ & $<0.001$ & $<0.001$ & $<0.001$ & $<0.001$ & 0.028 \\
\hline $\operatorname{LSD}(\mathrm{P}<0.05)$ & 6.50 & 2.00 & 0.18 & 0.18 & 0.20 & 0.17 & 0.18 & 0.17 & 44.86 \\
\hline
\end{tabular}

Note. $\mathrm{DAE}=$ Days after emergence, $\mathrm{HP}=$ hundred rice plants, $\mathrm{RL}=$ Root length.

Greater tillers per plant were recorded under rice intercropped with cymbopogon and desmodium both on-station (5.5 tillers \& 4.2 tillers) and on-farm (3.4 tillers \& 3.5 tillers) than under sole rice (3.8 tillers \& 2.8 tillers) at the 2 sites. Intercropping rice with cymbopogon, desmodium, mucuna and maize had no influence on the rice height, leaf number, leaf length and width of rice leaves at both stations. Intercropping mucuna or maize in rice reduced the number of rice tillers at all crop stages. At panicle initiation stage (55 DAE) the rice tillers reduced under intercropping with mucuna (2.8 tillers) and maize (2.7 tillers) on station and when intercropped with mucuna (2.3 tillers) or maize (1.0 tillers) on farm relative to the controls (3.8 tillers \& 2.8 tillers). Intercropping rice with cymbopogon, desmodium, mucuna and maize had no significant influences on the plant height, leaf number, leaf length and width of rice leaves, at both stations.

\subsection{Striga Weed Under Field Conditions}

On-farm, striga weed incidences per 100 rice plants (SHP) reduced due to intercropping with mucuna (22 striga), desmodium (27 striga) and cymbopogon (35 striga) relative to sole rice (81 striga). The SHP significantly (P $\leq$ $0.05)$, increased (110 striga) when rice was intercropped with maize. A higher striga incidence (63\%) was counted within $15 \mathrm{~cm}$ radius to rice plants.

\subsection{Nutrient Uptake and Soil Reserves for Potted Rice}

Potting rice with cymbopogon produced higher $\mathrm{N}(0.20 \mathrm{~g} / 100 \mathrm{~g})$ soil reserves at harvest than sole rice. The treatment also produced greater uptake of $\mathrm{N}(5.3 \mathrm{mg} / \mathrm{plant}), \mathrm{P}(0.65 \mathrm{mg} / \mathrm{plant})$ and $\mathrm{K}(12.62 \mathrm{mg} / \mathrm{plant})$ than other treatments including the control (Table 2). Potting rice with maize significantly $(\mathrm{P} \leq 0.05)$, lowered the rice soil $\mathrm{N}$ $(0.16 \mathrm{~g} / 100 \mathrm{~g}), \mathrm{P}(5.5 \mathrm{mg} / \mathrm{kg})$ and $\mathrm{K}(89.72 \mathrm{mg} / \mathrm{kg})$ reserves at harvest. Maize significantly reduced $\mathrm{K}$ uptake by rice $(5.6 \mathrm{mg} / \mathrm{plant})$ relative to sole rice. Potting rice with maize also produced lower rice uptake of $\mathrm{N}(2.7 \mathrm{mg} / \mathrm{plant})$ and $\mathrm{K}(5.6 \mathrm{mg} / \mathrm{plant})$ relative to other treatments. Potting rice with mucuna raised the uptake of $\mathrm{N}(4.6 \mathrm{mg} / \mathrm{plant})$ and $\mathrm{K}(70.85 \mathrm{mg} / \mathrm{plant}$ relative to sole rice. The $\mathrm{N} \& \mathrm{~K}$ uptake by rice potted with desmodium also increased (4.25 $\mathrm{mg} /$ plant \& $12.8 \mathrm{mg} / \mathrm{plant})$. Higher $\mathrm{K}$ uptake $(70.90 \mathrm{mg}$ per plant) by rice was recorded under rice potted with mucuna. Potting rice with mucuna, desmodium or maize did not influence the $\mathrm{P}$ uptake. 
Table 2. Soil nutrients at harvest and nutrient uptake for rice potted maize, desmodium, mucuna and cymbopogon

\begin{tabular}{llllllll}
\hline \multirow{2}{*}{ Potted plants } & \multicolumn{3}{c}{ Soil Nutrients at Harvest } & & \multicolumn{3}{c}{ Nutrient Uptake $(\mathrm{mg} / \mathrm{plant})$} \\
\cline { 2 - 3 } \cline { 6 - 7 } & $\mathrm{N}(\mathrm{g} / 100 \mathrm{~g})$ & $\mathrm{P}(\mathrm{mg} / \mathrm{kg})$ & $\mathrm{K}(\mathrm{mg} / \mathrm{kg})$ & & $\mathrm{N}$ & $\mathrm{P}$ & $\mathrm{K}$ \\
\hline Rice sole & $0.19 \mathrm{~b}$ & $8.95 \mathrm{~b}$ & $144.30 \mathrm{~b}$ & & $2.70 \mathrm{c}$ & $0.45 \mathrm{~b}$ & $7.30 \mathrm{c}$ \\
Rice/maize & $0.16 \mathrm{~d}$ & $5.56 \mathrm{f}$ & $89.72 \mathrm{c}$ & & $2.70 \mathrm{c}$ & $0.35 \mathrm{~b}$ & $5.60 \mathrm{~d}$ \\
Rice/desmodium & $0.17 \mathrm{c}$ & $9.64 \mathrm{a}$ & $144.32 \mathrm{~b}$ & & $4.52 \mathrm{~b}$ & $0.38 \mathrm{~b}$ & $12.80 \mathrm{~b}$ \\
Rice/cymbopogon & $0.20 \mathrm{a}$ & $7.83 \mathrm{c}$ & $144.30 \mathrm{~b}$ & & $5.30 \mathrm{a}$ & $0.65 \mathrm{a}$ & $12.62 \mathrm{~b}$ \\
Rice/mucuna & $0.19 \mathrm{~b}$ & $6.36 \mathrm{~d}$ & $152.10 \mathrm{a}$ & & $4.61 \mathrm{~b}$ & $0.45 \mathrm{~b}$ & $70.85 \mathrm{a}$ \\
$-\mathrm{P}$ & $<0.001$ & $<0.001$ & $<0.001$ & & $<0.001$ & 0.053 & $<0.001$ \\
LSD $(\mathrm{P}<0.05)$ & 0.008 & 0.008 & 0.082 & & 0.30 & 0.19 & 1.12 \\
\hline
\end{tabular}

Note. $\mathrm{N}=$ Nitrogen, $\mathrm{P}=$ Phosphorus, $\mathrm{K}=$ Potassium.

\subsection{Nutrient Uptake and Soil Reserves for Potted Maize}

Potting maize with mucuna reduced maize $\mathrm{P}$ uptake $(6.4 \mathrm{mg} / \mathrm{plant})$ and produced greater soil $\mathrm{N}(0.33 \mathrm{~g} / 100 \mathrm{~g})$, lower $\mathrm{P}(5.56 \mathrm{mg} / \mathrm{kg})$ and $\mathrm{K}(120.91 \mathrm{mg} / \mathrm{kg})$ nutrient reserves at harvest relative to sole maize crop (Table 3$)$. Potting maize with cymbopogon recorded greater uptake of maize $\mathrm{N}(92.50 \mathrm{mg} / \mathrm{plant})$ and $\mathrm{P}(8.2 \mathrm{mg} / \mathrm{plant})$ with significantly $(\mathrm{P} \leq 0.05)$ reduced soil $\mathrm{N}(0.16 \mathrm{~g} / 100 \mathrm{~g})$ and $\mathrm{P}(8.52 \mathrm{mg} / \mathrm{kg})$ but higher levels of $\mathrm{K}(163.82 \mathrm{mg} / \mathrm{kg})$ reserves than other treatments. Potting maize with desmodium increased the uptakes of $\mathrm{N}(112.5 \mathrm{mg} / \mathrm{plant}$ and $\mathrm{P}$ $(9.7 \mathrm{mg} / \mathrm{plant})$ with lower soil reserves of $\mathrm{P}(8.83 \mathrm{mg} / \mathrm{kg})$ and $\mathrm{K}(120.91 \mathrm{mg} / \mathrm{kg})$ than under sole maize. Potting maize with rice recorded lower $\mathrm{P}(5.5 \mathrm{mg} / \mathrm{plant})$ uptake with lower $\mathrm{N}(0.16 \mathrm{~g} / 100 \mathrm{~g}), \mathrm{P}(5.24 \mathrm{mg} / \mathrm{kg})$ and $\mathrm{K}(89.72$ $\mathrm{mg} / \mathrm{kg})$ soil nutrient reserves at harvest. Sole maize had relatively high $\mathrm{N}(0.19 \mathrm{~g} / 100 \mathrm{~g}), \mathrm{P}(9.53 \mathrm{mg} / \mathrm{kg})$ and K $(144.32 \mathrm{mg} / \mathrm{kg})$ nutrient soil reserves at harvest compared to maize with a component crops. The $\mathrm{N}$ uptake by maize was not influenced by mucuna and rice and the maize $\mathrm{K}$ uptake was not significant.

Table 3. Soil nutrient reserves at harvest and nutrient uptake for maize potted with rice, mucuna, cymbopogon, and desmodium

\begin{tabular}{|c|c|c|c|c|c|c|}
\hline \multirow{2}{*}{ Potted Plants } & \multicolumn{3}{|c|}{ Soil Nutrients at Harvest } & \multicolumn{3}{|c|}{ Nutrient Uptake (mg/plant) } \\
\hline & $\mathrm{N}(\mathrm{g} / 100 \mathrm{~g})$ & $\mathrm{P}(\mathrm{mg} / \mathrm{kg})$ & $\mathrm{K}(\mathrm{mg} / \mathrm{kg})$ & $\mathrm{N}$ & $\mathrm{P}$ & $\mathrm{K}$ \\
\hline Maize sole & $0.19 \mathrm{~b}$ & $9.53 \mathrm{a}$ & $144.32 \mathrm{~b}$ & $65.00 \mathrm{c}$ & $7.50 \mathrm{c}$ & $167.00 \mathrm{a}$ \\
\hline Maize + Desmodium & $0.19 \mathrm{~b}$ & $8.83 \mathrm{~b}$ & $120.91 \mathrm{c}$ & $112.50 \mathrm{a}$ & $9.70 \mathrm{a}$ & $190.50 \mathrm{a}$ \\
\hline Maize + Cymbopogon & $0.16 \mathrm{c}$ & $8.52 \mathrm{c}$ & $163.82 \mathrm{a}$ & $92.50 \mathrm{~b}$ & $8.20 \mathrm{~b}$ & $168.90 \mathrm{a}$ \\
\hline Maize + Mucuna & $0.33 \mathrm{a}$ & $5.56 \mathrm{~d}$ & $120.91 \mathrm{c}$ & $62.50 \mathrm{c}$ & $6.40 \mathrm{~d}$ & $168.10 \mathrm{a}$ \\
\hline Maize + Rice & $0.16 \mathrm{c}$ & $5.24 \mathrm{e}$ & $89.72 \mathrm{~d}$ & $67.50 \mathrm{c}$ & $5.50 \mathrm{e}$ & $225.00 \mathrm{a}$ \\
\hline P-value & $<0.001$ & $<0.001$ & $<0.001$ & $<0.001$ & $<0.001$ & 0.06 \\
\hline $\operatorname{LSD}(\mathrm{P}<0.05)$ & 0.008 & 0.008 & 0.046 & 9.20 & 0.35 & NS \\
\hline
\end{tabular}

Note. $\mathrm{N}=$ Nitrogen, $\mathrm{P}=$ Phosphorus, $\mathrm{K}=$ Potassium.

\subsection{Relative Growth Rates for Potted Rice and Maize on Station}

\subsubsection{Rice Potted with Cymbopogon, Mucuna, Desmodium or Maize}

The RGR for rice potted with desmodium (RD) was significantly greater $(\mathrm{P} \geq 0.05)$ between 14-28 days relative to other treatments (Figure 1). The RGR for rice potted with mucuna (RMc) significantly increased between 28-42 days relative to other treatments for the same period and the rice potted with maize (RMz) gave significantly lower RGR between 42 and 56 days relative to rice potted with desmodium, mucuna, cymbopogon and sole rice. 


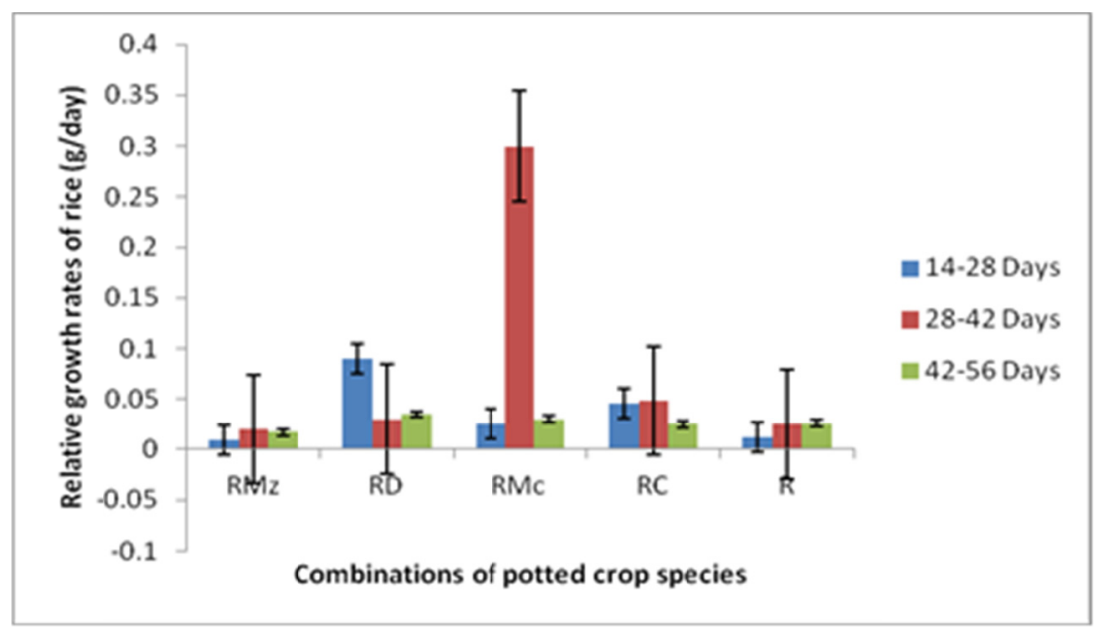

Figure 1. Relative growth rates of rice (R) potted with maize (RMz), desmodium (RD), mucuna (RMc) or cymbopogon $(\mathrm{RC})$

\subsubsection{Maize Potted With Cymbopogon, Mucuna, Desmodium or Rice}

The RGR for maize potted with desmodium, mucuna or cymbopogon were significantly greater than under sole maize and maize potted with rice between 14-28 days (Figure 2). RGR for maize potted with rice, significantly increased between 28-42 days. Maize potted with desmodium (MzD), mucuna (MzMc) and sole maize produced lower but similar RGR during the same period. Maize potted with mucuna gave greater RGR relative to maize potted cymbopogon during the same period. Between 42-56 days, higher RGR were recorded under maize potted with cymbopogon or rice. Lower RGR was under sole maize and maize potted with desmodium or mucuna. Maize RGR (14-28 days) increased under MzD, MzMc \& MzC and dropped (28-42 days) under MzD, RC \& MzMc.

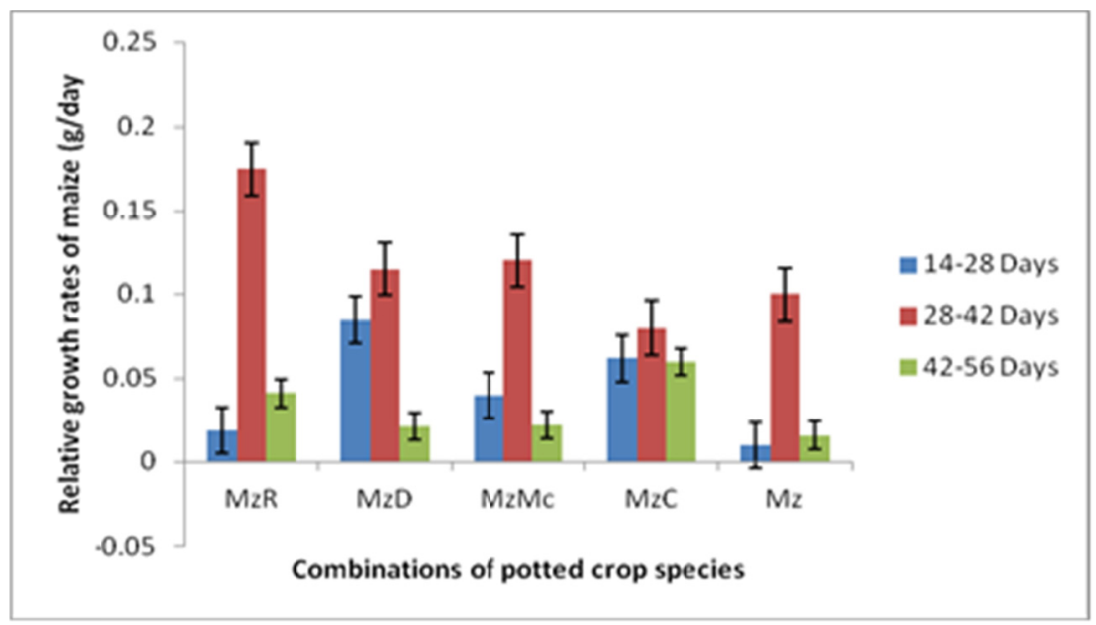

Figure 2. Relative growth rates of maize (Mz) potted with rice (RMz), desmodium (MzD), mucuna (MzMc) or cymbopogon $(\mathrm{MzC})$

\subsection{Yield Attributes, Yield and Competitive Indices for Intercropped Rice}

Intercropping desmodium, maize and mucuna in rice significantly $(\mathrm{P} \leq 0.05)$, reduced the number of rice panicles per plant at harvest on station. The number of rice panicles per plant reduced when rice was intercropped with mucuna at on farm (Table 4). The percent filled rice panicles and percent filled grains per panicle were not significant at both sites. Sole rice had higher grain yield than intercropped rice on farm and similar observations were made on station except that the yield of rice intercropped with cymbopogon $\left(1,103 \mathrm{~kg} \mathrm{ha}^{-1}\right)$ was similar to the 
sole rice grain yield. On farm, rice intercropped with desmodium produced lower rice grain yield than rice intercropped with cymbopogon (Table 4). Rice/maize and rice/mucuna intercropping systems had lower rice grain yields than all the other cropping systems.

Table 4. Yield parameters, yield, land equivalent and competitive indices for intercropped rice on station and on farm

\begin{tabular}{|c|c|c|c|c|c|c|c|c|}
\hline \multirow[b]{2}{*}{ Rice/Intercrops } & \multicolumn{2}{|c|}{ On-Station } & \multicolumn{2}{|c|}{ On-Farm } & \multicolumn{4}{|c|}{ Land Equivalent and competitive Ratios } \\
\hline & $\begin{array}{l}\text { Panicles } \\
\text { (per plant) }\end{array}$ & $\begin{array}{l}\text { Yield } \\
\left(\mathrm{kg} \mathrm{ha}^{-1}\right)\end{array}$ & $\begin{array}{l}\text { Panicles } \\
\text { (per plant) }\end{array}$ & $\begin{array}{l}\text { Yield } \\
\left(\mathrm{kg} \mathrm{ha}^{-1}\right)\end{array}$ & $\begin{array}{l}\text { PLER } \\
\text { (Rice) }\end{array}$ & $\begin{array}{l}\text { PLER } \\
\text { (Intercrops) }\end{array}$ & CLER & $\mathrm{CR}$ \\
\hline Rice sole & $7.80 \mathrm{a}$ & $1111 \mathrm{a}$ & $4.33 \mathrm{a}$ & $631 \mathrm{a}$ & $1.00 \mathrm{~b}$ & $1.00 \mathrm{c}$ & & \\
\hline Rice + Cymbopogon & $7.60 \mathrm{a}$ & $1103 \mathrm{a}$ & $4.08 \mathrm{a}$ & $510 \mathrm{~b}$ & $0.99 \mathrm{a}$ & $0.57 \mathrm{~b}$ & $1.56 \mathrm{a}$ & $1.60 \mathrm{~b}$ \\
\hline Rice +Desmodium & $5.10 \mathrm{~b}$ & $926 \mathrm{~b}$ & $4.33 \mathrm{a}$ & $492 \mathrm{c}$ & $0.83 \mathrm{~b}$ & $0.85 \mathrm{a}$ & $1.68 \mathrm{a}$ & $0.65 \mathrm{~d}$ \\
\hline Rice + Maize & $4.60 \mathrm{~b}$ & $750 \mathrm{c}$ & $3.58 \mathrm{a}$ & $394 \mathrm{~d}$ & $0.68 \mathrm{c}$ & $0.33 \mathrm{c}$ & $1.00 \mathrm{~b}$ & $1.48 \mathrm{~b}$ \\
\hline Rice +Mucuna & $3.70 \mathrm{~b}$ & $728 \mathrm{c}$ & $2.50 \mathrm{~b}$ & $359 \mathrm{~d}$ & $0.66 \mathrm{c}$ & $0.34 \mathrm{c}$ & $1.00 \mathrm{~b}$ & $1.79 \mathrm{a}$ \\
\hline P-Value & 0.23 & 0.004 & 0.68 & 0.003 & $<0.001$ & $<0.001$ & $<0.001$ & $<0.001$ \\
\hline LSD $\mathrm{P}<0.05)$ & 2.40 & 73.1 & 1.64 & 111.3 & 0.05 & 0.05 & 0.54 & 0.165 \\
\hline
\end{tabular}

Note. PLER $=$ Partial Land Equivalent Ratio, CLER $=$ Combined Land Equivalent Ratio, $\mathrm{CR}=$ Competitive Ratio.

\subsection{Competitive Indices of Rice on Station}

Cymbopogon gave the highest (1.00) partial land equivalent ratio (LER) followed by desmodium (0.8). Rice intercropped with maize or mucuna recorded the lowest partial LER (0.7) for rice. The partial land equivalent ratio for intercrops were highest under desmodium (0.9) followed by cymbopogon (0.6) and lowest under maize and mucuna (0.3). The combined land equivalent ratios for rice/cymbopogon and rice/desmodium intercropping systems were 1.6 and 1.7 respectively. Rice/maize and rice/mucuna intercropping systems had each LER of 1.0. Mucuna was the most competitive intercrop with a competitive ratio (CR) of 1.8 followed by cymbopogon (1.6) and maize (1.5). Desmodium had a significantly lower competitive ratio $(0.7)$ when intercropped with rice compared to all the other crops.

\section{Discussions}

\subsection{Growth of Rice and Maize in a Screen House}

Rice potted with cymbopogon and mucuna increased in height relative to rice potted with maize. The increased rice height with cymbopogon and mucuna component crops may be attributed to the observed significantly higher $\mathrm{N}$ (96\%), P (44\%) and K (73\%) nutrient uptake by rice potted with cymbopogon and the higher N (70\%) and K (871\%) uptake when potted with mucuna, relative to sole rice and rice potted with maize NPK uptake that were at par under the current study. The increased nutrient uptake by rice could have been influenced by compounds released in the root exudates of cymbopogon and mucuna plants. Tomita et al. (2003), and Li et al. (2010) reported reduced nutrient absorption and crop growth rates due to allelochemicals. Effects of allelochemicals on nutrient uptake in tomatoes were also observed by F. Cheng and Z. Cheng (2015). Kaiira et al. (2019) identified 5 terpenoids namely naphthalene, 1,2-dimethyl-4-ethylbenzene, 1,3-ditertiarybutylbenzene, 1-ethyl-3-methyl-benzene, 1,3-dichloro-benzene, an alkane called n-tetra-decane and a phenol named dihydrocarveol in root exudates of Mucuna pruriens. The researchers also profiled 3 terpenoids in root exudates of Cymbopogon nardus namely tert-amyl benzene, pent methyl benzene, 1, 2, di-tert-butyl benzene and an alkane named 2,3-dimethylundecane and 2-ethylhexanol phenol. Some of these terpenoids, alkanes and phenols could have enhanced the observed nutrient uptake levels in the current study.

Rice root length reduced when potted with cymbopogon, mucuna, desmodium and maize relative to sole rice. This may be attributed to allelopathic inhibitory influences of secondary metabolites in root exudates of the test plants on processes such as protein and amino acid synthesis, respiration and cell division that promote crop growth. Prapaipit et al. (2013) reported higher sensitivity to allelopathic extracts by the roots of all the test plants than their shoots. Kaiira et al. (2019) profiled and reported several terpenoids, phenols, alkanes and furans in the root exudates of cymbopogon, mucuna, desmodium and maize. Some of the identified compounds could be responsible for the declined root length.

Maize leaf length significantly increased when potted with desmodium (17\%) and mucuna (31\%). This related to the corresponding high relative growth rates under the two treatments in the current study and may be attributed to observed higher N (73\%), P (29\%) and K (141\%) uptake by maize potted with desmodium relative to sole maize. 
Maize potted with mucuna recorded lower (15\%) P uptake relative to sole maize. The $\mathrm{N}$ and $\mathrm{K}$ uptake levels were similar to sole maize. Thus, the higher maize leaf growth may not be attributed to influences of nutrients taken by maize but could have resulted from etiolating due to competition between maize and mucuna for solar radiation. Mucuna crop is highly competitive and recorded the highest competitive ratio with rice in the current study.

Height of rice potted with maize significantly reduced relative to rice potted with cymbopogon or mucuna crops. This may be partly attributed to competition for water and nutrients in the rhizosphere between the cereal crops. Rice crop potted with maize also had significantly lower K (23\%) nutrient uptake levels relative to sole rice in the current study. Significantly higher N, P and K $(96 \%, 44 \%$ \& $73 \%)$ uptake levels were in the current study recorded when rice was potted with cymbopogon relative to sole rice and higher $\mathrm{N}$ and $\mathrm{K}(70 \% \& 871 \%)$ uptake by rice were also observed under rice crop with component mucuna. The high nutrient uptake levels by rice potted with cymbopogon and mucuna corresponded to the higher relative growth rates recorded in this study under rice potted with both crops relative to the maize intercrop. Nutrient uptake could have been influenced by compounds in crop root exudates as earlier reported. F. Cheng and Z. Cheng (2015) reported that allelochemicals can inhibit the activities involved in the absorption and transport of ions at the cell plasma membrane and this suppresses the cellular absorption of $\mathrm{K}^{+}, \mathrm{Na}^{+}$or other ions. The current study indicates high potential to rice intercropping with cymbopogon and in the maize intercropping with desmodium. The maize/rice ecosystem exhibited low nutrient uptake with poor crops growth and may not be sustainable given its low productivity potential.

\subsection{Rice Tillers and Striga Weeds Under Field Conditions}

Striga weeds incidences reduced (57-73\%) due to intercropping with mucuna, desmodium and cymbopogon but the incidence increased $(80 \%)$ when intercropped with maize. Little work has been done on striga control using desmodium, mucuna and cymbopogon, But, Khan et al. (2006) indicated that intercropping cereals, mainly with legumes can reduce the number of striga plants. Potentially, legumes act as traps crops stimulating suicidal striga germination or may alter the microclimate under the crop canopy and interfere with striga germination and development (Khan et al., 2006). Mucuna, desmodium and cymbopogon could have released compounds in the root exudates that similarly changed the micro environment in the canopy and or stimulated suicidal striga germination. It is postulated that nitrogen fixed by desmodium legume crop could have interacted with striga growth, as increasing the amount of available nitrogen was reported to reduce striga densities (Pieterse et al., 1991).

The reduced striga counts under mucuna, desmodium and cymbopogon intercrops may also be attributed to influences of bio-active compounds exudates by the host plants into the rhizosphere that could have interfered with the processes of striga germination and development. Kaiira et al. (2019) identified five terpenoids, one phenol and an alkane in mucuna exudates. Desmodium plants released three terpenoids, one alkane and a furan while cymbopogon crop released five terpenoids, a phenol and an alkane. Some of these compounds were associated with inhibited weed and crop growth and could have inhibited striga weed attachment and growth. Pickett (2010) indicated a putative allelopathic mechanism by $D$. uncinatum as evident in the control of $S$. hermonthica. Allelopathic control of other weeds by the test plants have been observed by Suwitchayanon et al. (2013) using $C$. nardus (L.) and Soares et al. (2014) reported that L-DOPA from mucuna root exudates reduced the growth of neighboring plants.

Striga hermonthica count increased (36\%) under rice/maize intercropping system relative to sole rice with a higher count (63\%) of the weed on maize. This may be attributed to stimulatory influences of compounds in root exudates of rice and maize on processes that enhance the germination, growth and development of striga. Kaiira et al. (2019) observed a furan namely 2-n-pentylfuran, one alkane named 2,3-dimethylundecane and six terpenoids namely 1,2-dimethyl-3-ethyl benzene, 1-methyl-2-(2-propenyl)benzene, tert-amyl benzene, 1-sec-butyl-4methylbenzene, 1,3-di-tert-butylbenzene and pent methyl benzene in the root exudates of upland NERICA 1. Maize crop root exudates released 5 terpenoids namely O-dichlorobenzene, 1-methyl-2-(2-propenyl) benzene, m-ethyl toluene, 1, 2, 4-trimethylbenzene, 2-ethyl-p-xylene and one furan called 2-n-pentylfuran. Some of the compounds possibly supported striga weed attachment and growth in a similar mode to strigolactone, a compound reported to stimulate striga attachment to cereal crops.

Greater numbers of rice tillers were recorded at panicle initiation stage under intercropping with cymbopogon and desmodium compared to the sole crops, at all crop stages, both on station and on farm. This may be attributed to the significantly higher $\mathrm{N}(67 \%) \& \mathrm{~K}(75 \%)$ nutrient uptake levels for rice intercropped with desmodium and for $\mathrm{N}$ (96\%), P (44\%) and K (73\%) under rice intercropped with cymbopogon relative to sole rice crop. The height of maize plants and number of rice tillers reduced due to intercropping maize with rice or mucuna on farm relative to sole cereal crops. This was associated with the observed higher competitive ability of mucuna and maize indicated 
by the higher competitive indices for both crops recorded in the current study. Maize potted with rice recorded reduced $\mathrm{P}(27 \%)$ nutrient uptake in the current study which could have led to the lower relative growth rates observed under the treatments. Phosphorus enhances development of crop primary roots and thus improves stem and tiller development. The inhibited maize leaf length and number of rice tillers could also be associated with intra-species competition for nutrients in the rhizosphere by the two cereal crops (maize \& rice). High incidences of Striga hermonthica obligate parasitic weeds recorded on the two crops under the current study may have similarly impacted on physiological crop processes such as nutrient uptake, cell division, respiration and photosynthesis in maize and rice, reducing maize and rice growth.

Raven (1983) reported that parasitic plants that drain nutrients and water through the xylem transpire relatively large amount of water than their hosts. This higher rate of transpiration not only diverts the xylem sap to the parasite but also reduces the water supply around the host rhizosphere. Constantine et al. (2013), and Mbogo et al. (2013) reported negative correlation between emerged striga and grain yield of rice and maize, respectively. Taylor and Seel (1998) indicated that while the stomata conductance of infected maize plants was reduced, that of parasite (Striga hermonthica) remained higher. The higher rates of stomata conductance in parasites results into higher rates of derived host photosynthates, water and mineral salts to the parasites translocation systems. NERICA 1 rice was less susceptible to striga than LONGE $6 \mathrm{H}$ maize. This may be attributed to its higher genetic resistance to striga weeds as reported by Rodenburg et al. (2015). The reduction in tillers between 36-55 DAE under all treatments may be attributed to mortality of late emerging tillers due to reduced photosynthates to the sinks. Late emerging tillers were reported not to mature and contribute to the grain yield of rice by Wang et al. (2007).

\subsection{Yield Attributes and Yield for Intercropped Rice On-Station and On-Farm}

Intercropping rice with cymbopogon produced higher rice grain yield and combined land equivalent ratios amongst intercropping systems. The current study indicates that a farmer would need 1.56 acres of land area planted with sole rice to achieve equal productivity from 1.0 acre of rice intercropped with cymbopogon. Planting rice and cymbopogon in the same pot were in the current study observed to exhibit maximum rice growth, N, P and $\mathrm{K}$ uptake and increased rice tiller development that could have contributed to the observed high rice grain yield. Rana et al. (2013) indicated benefits from rice intercropping with other crops. Based on the observations under this study, selection of the right component crops under mixed cropping systems is paramount and their allelopathic potential must be considered.

\section{Conclusions}

Rice root growth significantly reduced when potted with desmodium, maize, mucuna or cymbopogon. Rice plant height significantly increased when potted with cymbopogon and mucuna but reduced when potted with maize. Maize leaf length increased significantly when potted with desmodium, cymbopogon and mucuna. The relative growth changes were attributed to secondary metabolites. Intercropping rice and mucuna significantly reduced the striga weed count relative to sole rice. Rice/cymbopogon intercropping system under paired rows of rice maximized productivity with high crop competition and relative growth rates. There were higher economic benefits from Rice/Cymbopogon and Rice/Cymbopogon intercropping ecosystems from unit area than under sole cropping. The maize/rice ecosystem exhibited low nutrient uptake with lower RGR for both crops and had the lowest benefits from intercropping. Rice intercropping with cymbopogon is productive under paired row ecosystem. Maize/rice intercropping system is not recommended because of its low productivity potential.

\section{References}

Burgos, N. R., Talbert, R. E., Kim, K. S., \& Kuk, Y. I. (2004). Growth inhibition and root ultra structure of cucumber seedlings exposed to allelochemicals from rye (Secale cereale). J. of Chemical Ecology, 30, 671-689. https://doi.org/10.1023/B:JOEC.0000018637.94002.ba

Chaimovitsh, D., Rogovoy, O., Altshuler, O., Belausov, E., Abu-Abied, M., Rubin, B., ... Dudai, N. (2012). The relative effect of citral on mitotic microtubules in wheat roots and BY2 cells. The Plant Biology, 14(2), 354-364. https://doi.org/10.1111/j.1438-8677.2011.00511.x

Cheng, F., \& Cheng, Z. (2015). Research progress on the use of plant allelopathy in agriculture and the physiological and ecological mechanisms of allelopathy. Frontiers in Plant Science, 6, 1020. https://doi.org/10.3389/fpls.2015.01020

Constantine, J., Sibuga, K. P., Rodenburg, J., Kayeke, J., \& Kabiri, S. (2013). Effects of varying densities of Striga asiatica and Rhamphicarpa fistulosa on growth and physiology of rice. African Crop Science Conference Proceedings, 11, 87-96. 
Geng, G. D., Zhang, S. Q., \& Cheng, Z. H. (2009). Effects of different allelochemicals on mineral elements absorption of tomato root. China Vegetables, 4, 48-51.

Gozubelin, H., Kilinc, M., Sener, O., \& Konuskan, O. (2004). Effects of single and twin row planting on yield components in maize. Asian J. of Plant Sciences, 3, 203-206. https://doi.org/10.3923/ajps.2004.203.206

Harun, M. A. Y. A., Robinson, R. W., Johnson, J., \& Uddin, M. N. (2014). Allelopathic potential of Chrysanthemoides monilifera subsp. Monilifera (boneseed): A novel weapon in the invasion processes. South African J. of Botany, 93, 157-166. https://doi.org/10.1016/j.sajb.2014.04.008

Jabran, K., Mahajan, G., Sardana, V., \& Chauhan, B. S. (2015). Allelopathy for weed control in agricultural systems. Crop Protection, 72, 57-65. https://doi.org/10.1016/j.cropro.2015.03.004

Kaiira, M. G., Chemining'wa, G. N., Ayuke, F., \& Baguma, Y. (2019). Profiles of compounds in root exudates of rice, cymbopogon, desmodium, mucuna and maize. J. of Agricultural Sciences, 64(4), 125-133. https://doi.org/10.2298/JAS1904399K

Kaiira, M. G., Chemining'wa, G. N., Ayuke, F., Baguma, Y., \& Atwijukire, E. (2021a). Profiles of compounds in stover of rice, cymbopogon, desmodium, mucuna and maize. J. of Agricultural Science, in press.

Kaiira, M. G., Chemining'wa, G. N., Ayuke, F., Baguma, Y., \& Atwijukire, E. (2021b). Allelopathic potential of compounds in selected crops. J. of Agricultural Science, in press.

Kanampiu, F., Makumbi, D., Mageto, E., Omanya, G., Waruingi, S., Musyoka, P., \& Ransom, J. (2018). Assessment of management options on striga infestation and maize grain yield in Kenya. Weed Science, 66(4), 1-9. https://doi.org/0.1017/wsc.2018.4

Khan, Z. R., Midega, C. A. O., Hassanali, A., Pickett, J. A., Wadhams, L. J., \& Wanjoya, A. (2006). Management of witchweed, Striga hermonthica, and stemborers in sorghum, Sorgum bicolar, through intercrpping with greenleaf desmodium, Desmodium intortum. International J. of Pest Management, 52(4), $297-302$. https://doi.org/10.1080/09670870600816991

Khan, Z. R., Pickett, J. A., Wadhams, L. J., Hassanali, A., \& Midega, C. A. O. (2006). Combined control of Striga hermonthica and stem borers by maize-Desmodium spp. intercrops. Crop Protection, 25, 989-995. https://doi.org/10.1016/j.cropro.2006.01.008

Li, Z.-H., Wang, Q., Ruan, X., Pan, C.-D. P., \& Jiang, D.-A. (2010). Phenolics and Plant Allelopathy. Molecules, 15(12), 8933-8952. https://doi.org/10.3390/molecules 15128933

Mbogo, P. O., Dida, M., \& Owuor, B. (2016). Effect of Striga hermonthica (Del.) Benth on yield and yield components of maize (Zea mays L.) hybrids in Western Kenya. J. of Agricultural Science, 8(8), 112. https://doi.org/10.5539/jas.v8n8p112

Mead, R., \& Willey, R. W. (1980). The concept of land equivalent ratio and advantages. Experimental Agriculture, 16, 217-226. https://doi.org/10.1017/S0014479700010978

Nishida, N., Tamotsu, S., Nagata, N., Saito, C., \& Sakai, A. (2005). Allelopathic effects of volatile monoterpenoids produced by Salvia leucophylla: Inhibition of cell proliferation and DNA synthesis in the root apical meristems of Brassica campestris seedlings. J. of Chemical Ecology, 31, 1187-1203. https://doi.org/ 10.1007/s10886-005-4256-y

Okalebo, J. R., Gathua, K. W., \& Woomer, P. L. (2002). Laboratory methods of soil and plant analysis: A working manual (2nd ed.). TSBF-CIAT and SACRED Africa, Nairobi.

Pickett, J. A., Hamilton, M. L., Hooper, A. M., Khan, Z. R., \& Midega, C. A. O. (2010). Companion cropping to manage parasitic plants. Phytopathology, 48, 161-177. https://doi.org/10.1146/annurev-phyto-073009114433

Pieterse, A. H., \& Verkleij, J. A. (1991). Effect of soil condition on Striga development-A review. In J. K. Ransom, L. J. Musselman, A. D. Worsham, \& C. Parker (Eds.), Striga. Proceedings of the $5^{\text {th }}$ international symposium of parasitic weeds (pp. 329-339). CIMMYT, Nairobi, Kenya.

Rana, M. M., Bhuiya, M. S. U., \& Akhand, M. I. M. (2013). Effect of intercropping of Sesbania rostrata with transplant. Aman rice on yield and profitability. J. of Agriculture and Veterinary Science, 2(1), 10-14. https://doi.org/10.9790/2380-0211014

Raven, J. A. (1983). Phytophages of xylem and phloem: A comparison of animal and plant sap-feeders. Advances in Ecological Research, 13, 135-234. https://doi.org/10.1016/S0065-2504(08)60109-9 
Rodenburg, J., Cissoko, M., Kayeke, J., Dieng, I., Khan, Z. R., Midega, C. A. O., ... Scholes, J. D. (2015). Do NERICA rice cultivars express resistance to Striga hermonthica (Del.) Benth and Striga asiatica (L.) Kuntze, under field conditions? Field Crops Research, 170, 83-94. https://doi.org/10.1016/j.fcr.2014.10.010

Soares, A. R., Marchiosi, R., Signeira, S. R., Barbosa, L. R., Dantas, S. W., \& Farrarese, F. O. (2014). The role of L-DOPA in plants. Plant Signaling and Behavior, 9, e28275. https://doi.org/10.4161/psb.28275

Suwitchayanon, P., Pukclai, P., \& Kato-Noguchi, H. (2013). Allelopathic activity of Cymbopogon nardus (Poaceae). Journal of Plant Studies, 2(2), 1-6. https://doi.org/10.5539/jps.v2v2p1

Taylor, A., \& Seel, W. E. (1998). Do Striga hermonthica induced changes in soil matric potential cause thereduction in stomatal conductance and growth of infected maize plants? New Phytology, 138, 67-73. https://doi.org/10.1046/j.1469-8137.1998.00895.x

Tomita, K., Fujii, Y., Yoshida, S., Hashimoto, H., \& Yamashita, M. (2003). Volatile allelopathy in velvet bean (Mucuna pruriens L.) and gravity. Biological Sciences in Space, 17(3), 212-213.

Wang, F., Cheng, F. M., \& Zhang, G. P. (2007). Difference in grain yield and quality among tillers in rice rice genotypes differing in tillering capacity. Rice Science, 14, 135-140. https://doi.org/10.1016/S1672-6308 (07)60019-5

Willey, R. W. (1979). Intercropping-Its importance and research needs. Part 1. Competition and yield advantages. Field Crops Abstract, 32, 1-10.

Willey, R. W., \& Rao, M. R. (1980). A competitive ratio for quantifying competition between intercrops. Experimental Agriculture, 16, 117-125. https://doi.org/10.1017/S0014479700010802

\section{Copyrights}

Copyright for this article is retained by the author(s), with first publication rights granted to the journal.

This is an open-access article distributed under the terms and conditions of the Creative Commons Attribution license (http://creativecommons.org/licenses/by/4.0/). 